\title{
Government's Role in Preventing the Theft During and After Natural Disasters
}

\section{Ambara Dewita Purnama ${ }^{1}$, M. Syukri Akub², Hijrah Adhyanti Mirzana ${ }^{3}$}

\author{
${ }^{I}$ Faculty of Law, Universitas Hasanuddin, Indonesia, \\ E-mail:ambaradewitapurnama@gmail.com \\ ${ }^{2}$ Faculty of Law, Universitas Hasanuddin, Indonesia, E-mail: akubsyukri@gmail.com \\ ${ }^{3}$ Faculty of Law, Universitas Hasanuddin, Indonesia, E-mail: adhyantihijrah@gmail.com
}

\section{Article Info}

Keywords:

Crime; Theft; Natural Disasters;

Government.

How to cite:

Ambara Dewita Purnama, $M$. Syukri Akub, Hijrah Adhyanti Mirzana, "Government's Role in Preventing the Theft During And After Natural Disasters", Fiat Justisia: Jurnal Ilmu Hukum 14, no. 4 (2020): 353-362.

DOI:

10.25041/fiatjustisia.v14no4.1927

\begin{abstract}
Weak supervision and security during and after natural disasters have created new problems. The crime of theft is now rife at the time and after natural disasters. This study aims to determine the government's role in preventing theft during and after natural disasters in the city of Palu. This research is empirical legal research with a criminological approach. The study was conducted in Palu City, Central Sulawesi. The results of this study indicate that the government's role in efforts to prevent theft can only overcome theft crimes that are motivated by the urgent need of victims of natural disasters and cannot cope with theft that are motivated by opportunity.
\end{abstract}

\section{A. Introduction}

Crime is an act that can cause the offender to be punished. ${ }^{1}$ The crime that is rife in our environment is a crime against property, one of which is larceny. Larceny is taking of property from the possession of another intending to appropriate it legally. ${ }^{2}$ Theft explained in Article 362 of the Criminal Code (KUHP) which states that: "whoever takes an item, which entirely or partially belongs to another person to own the item against the right, is punished for

\footnotetext{
${ }^{1}$ Chintya Dewi Restyana S, "The Modus Operandi of Children as the Offender in Committing Human (A Study in Kepolisian Resor Kota Besar Surabaya)", Fiat Justisia: Jurnal Ilmu Hukum 13, no. 1, (2019): 75-86. DOI: https://doi.org/10.25041/fiatjustisia.v13no1.1508.

${ }^{2}$ M. Marwan, Jimmy P, Kamus Hukum: Dictionary of Law Complete Edition (Surabaya: Reality Publisher, 2009), 499.
} 
theft with a prison sentence. Five years or a maximum fine of Rp.900.00 (nine hundred rupiahs). ${ }^{3}$

A crime that has fulfilled the elements of Article 362 KUHP, the theft has occurred, and there is no question whether the victim of the theft feels loss or not. ${ }^{4}$ The Criminal Code regulates 5 (five) types of theft namely ordinary theft (Article 362), aggravated theft (Article 363), light theft (Article 364), robbery (Article 365) and theft in the family circle (Article 367). $)^{5}$ The definition of theft according to the Draft Book of the Criminal Code (R-KUHP) Chapter XXIV concerning the crime of theft Article 482, reads: theft, with a maximum imprisonment of 5 (five) years or a maximum fine of category $\mathrm{V}$ " ${ }^{6}$ The penalty contained in category V Article 79 paragraph (1) letter e R-KUHP is Rp. 500,000,000.00 (five hundred million rupiahs).

The theft that committed at the time of natural disaster is aggravated crime as explained in Article 363 Paragraph (1) $2^{7}$ It is sentenced to imprisonment for a maximum of 7 (seven) years if committing the theft during a fire, eruption, flood, earthquake or seaquake, volcanic eruption, submarine, shipwreck, train accident, riot, rebellion or wartime woes. ${ }^{8}$ One of the things that are most often experienced by people during and after natural disasters ${ }^{9}$ Is the weak security controls in the affected area making it easier for others to take advantage of the situation as an opportunity to commit theft because at that time most property owners were busy save themselves and choose to flee? Natural disasters always have a surprising and detrimental effect on property and the loss of life. ${ }^{10}$ As a form of protection of public property left behind due to natural disasters, efforts to combat crime are needed not only by law enforcement officials but also by the government's role. Crime prevention measure as an effort to protect the community and achieve community welfare. ${ }^{11}$

${ }^{3}$ R. Soesilo, Kitab Undang-Undang Hukum Pidana (KUHP) Serta Komentar-Komentarnya Lengkap Pasal Demi Pasal (Bogor: Politeia, (1995), 249.

${ }^{4}$ Amir Ilyas, Asas-Asas Hukum Pidana; Memahami Tindak Pidana dan Pertanggungjawaban Pidana Sebagai Syarat Pemidanaan, Disertai Teori-Teori Pengantar dan Beberapa Komentar (Yogyakarta: Rangkang Education, 2012), 36.

${ }^{5}$ Wahyu Nugroho, "Disparities Hukuman dalam Perkara Pidana Pencurian dengan Pemberatan (Kajian Terhadap Putusan Nomor 590/Pid.B/2007/PN.Smg dan Nomor 1055/Pid.B/2007/PN.SMg”, Jurnal Yudisial 5, no. 3, (2012): 261-282. DOI: http://dx.doi.org/10.29123/jy.v5i3.124.

${ }^{6}$ Manuscript Program of the Criminal Code (RKUHP), September, (2019), p.118

${ }^{7}$ Decision of the Palu District Court Nomor 513/Pid.B/2018/PN.Pal, (2019), p.1-11

${ }^{8}$ R. Soesilo, Op.Cit., 250-251.

${ }^{9}$ During natural disasters, which are Friday through Sunday, 28 to September 30, 2018, and after passing natural disasters on Monday to Friday, 1 through October 122018.

10 Hariyadi Djamal, Gatot Saptadi. "Kajian Model Desa Tangguh Bencana dalam KesiapsiagaanPenanggulangan Bencana Bersama BPBD Provinsi D.I. Yogyakarta", Jurnal Penanggulangan Bencana 3, no. 2, (2012): 1-13.

${ }^{11}$ Nasrun Pasaribu, et al., "Penyidikan Kasus Tindak Pidana Pencurian dengan Pemberatan di Wilayah Hukum Polsek Medan Baru”, USU Law Journal 5, no. 1, (2017):30-40. 
An earthquake measuring 7.7 on the Richter scale with an epicentre at 27 $\mathrm{km}$ Northeast of Donggala, Central Sulawesi, followed by a 2-meter high tsunami around the West Coast of Central Sulawesi Province on Friday, September 28, 2018, at around 18.02 WITA, resulting in paralysis of various sectors in the city of Palu. ${ }^{12}$ Because of this event, the Governor of Central Sulawesi issued Decree Number 466/459/BPBD/2018 which essentially stipulated the emergency response period for handling the earthquake and tsunami disaster in Central Sulawesi Province for 14 (fourteen) days from Saturday, September 29, 2018, until Friday' at October 12 2018. ${ }^{13}$ Lack of security during and after natural disasters in the city of Palu was made an opportunity for others to commit the theft. Efforts to overcome these crimes in addition to law enforcement also need to know how the government's role as leaders who care about the fate of the people ${ }^{14}$ In order to overcome the theft in the event or/and after natural disasters in the city of Palu, Central Sulawesi.

Crime prevention measure in criminology is divided into 3 (three) main parts, including (1) pre-emptive, namely early efforts to prevent the emergence of an intention to commit a crime. This is done through the inculcation of values and norms so that they are internalized in someone so that even if there is an opportunity to commit a crime, there is no intention at all because of the values and norms embedded in him; (2) preventive as a follow-up effort after pre-emptive. Both are still at the level of preventing crime, but the difference is that preventive efforts are made to eliminate the opportunity for the offender to not commit a crime, for example installing alarms at home as a warning if someone else tries to enter the house; and (3) repressive measures are efforts carried out by imposing sentences on perpetrators of crimes, for example, perpetrators of crimes convicted with imprisonment. This effort aims to have the deterrent effect for the perpetrators as a result of their actions and do not repeat the actions in the future. ${ }^{15}$

Based on the problems that have been explained, it is relevant to be examined through research on the role of government that has been carried out in preventing the rampant of theft during and after natural disasters at city of Palu, Central Sulawesi Province.

The purpose of this research was to determine the role of government in preventing theft during and after natural disasters. Besides, it is hoped that this research can be a reference for the government to better prepare early for any

\footnotetext{
${ }^{12}$ Reddy Mas Sahid, "Sosiologi Pemerintahan: Penjarahan di Kota Palu, Faktor, Aktord an Penanggulangan", The Indonesian Journal of Politics and Policy (IJPP)1, no. 1, (2019):83-93. ${ }^{13}$ Palu District Court Decision Number 525/Pid.B/2018/PN.Pal (2018), p.1-15.

${ }^{14}$ Oksidelfa Yanto, Muhammad Iqbal, "Protection of Teacher Profession Encountered with The Rule of Criminal Law on Child Protection", Tadulako Law Review 4, no. 2, (2019):183-201.

15 A. S. Alam, Amir Ilyas, Kriminologi Suatu Pengantar (Jakarta: Prenadamedia Group, 2018), 92-93.
} 
possibility that will arise to minimize the impact of a natural disaster occur at a time when disasters have recently begun to occur in many regions.

In order to examine a society focused on the legal view as a set of reality, actions and behaviour, ${ }^{16} \mathrm{~A}$ suitable research method used in this study is an empirical research method through approaches to crime prevention. ${ }^{17}$ This research was conducted at the Palu City Police Criminal Investigation Unit (Satreskrim Polres) and the Government through the Regional Disaster Management Agency (BPBD) of Palu City, Central Sulawesi. This research uses the following types of data: (1) primary data obtained from field research through interview methods to members of the police as well as members of regional disaster management agencies directly involved in disaster management; and (2) secondary data in the form of literature or documents that are relevant to the writing material that can be obtained through the library or documentation from relevant agencies. The data obtained will be analyzed using qualitative descriptive methods to describe all the data obtained in a clear and detailed manner and then analyzed in order to answer the problems of this research under study regarding the government's role in preventing the theft during and after natural disasters.

\section{B. Discussion}

Natural disasters that occur in the city of Palu affect the occurrence of theft. This theft is carried out in a particular situation where the condition of the place (locus) of the case occurred in the area affected by the disaster. ${ }^{18} \mathrm{As}$ in the data of the Criminal Investigation Unit of Resort Police in Palu City, the occurrence of this natural disaster affected the increase in the number of theft cases in Palu City, in the previous six months, namely March 2018 to August 2018, there were only 445 cases. However, in the following six months, September 2018 to February 2019, it increased to 466 cases. A total of 42 cases that occurred during the Palu City disaster emergency response began on September 29 to October 11, 2018, with a total of 144 people handled by four police agencies including the Palu City Police, the West Palu Sector Police, the East Palu Sector Police, and the Police South Palu Sector. ${ }^{19}$ The 42 cases and 144 of these perpetrators, there were 21 cases and 110 perpetrators used as samples.

As the number of samples has been determined, obtained the fact that as many as 35 perpetrators aged adults, ten perpetrators of child age and 65 other

\footnotetext{
${ }^{16}$ Ahmad Ali, Menguak Teori Hukum (Legal Theory) dan Teori Peradilan (Judicial Prudence) Termasuk Interpretasi Undang-Undang (Legisprudence) (Jakarta: Kencana Prenadamedia Group, 2009), 178.

${ }^{17}$ Chintya Dewi Restyana S, Op.Cit.,78.

${ }^{18}$ Agus Suharsoyo, "Karakter Pelaku Tindak Pidana Pencurian Dalam Tipologi Kejahatan Pencurian di Wilayah Sukoharjo", Jurisprudence 5, no. 1, (2015): 64-74.

${ }^{19}$ Data of the Criminal Investigation Unit of the Palu City Resort Police, Central Sulawesi
} 
perpetrators unknown age. All of these perpetrators are male. Thirty-four perpetrators have different types of work, one person is unemployed, while 75 others are unknown.

Most of the perpetrators are not from Palu City. Some perpetrators come from Luwuk, Banggai Regency which travels a distance of about $592.6 \mathrm{~km}$ for 12 hours 22 minutes to get to the city of Palu, with this distance, of course, the theft of crimes committed by perpetrators in the city of Palu is motivated because of the intention to take advantage of the opportunity. Of the 21 cases, 10 cases were known to have committed the theft by using a type of vehicle such as truck, pick-up car and minivan as facilities aimed at transporting stolen goods, while 11 other cases were unknown. The types of tools used by perpetrators of theft are also varied, such as a $\mathrm{T}$ key, a wrench, a screwdriver, a hammer, a hose, a large and small crowbar, and betel. Most of these tools are used to disassemble ATMs. ${ }^{20}$

The theft was carried out in the mostly morning at around 05.30 Central Indonesian Time or noon until the afternoon at 16:30 Central Indonesian Time because the condition of the City of Palu at that time was still minimal supervision from the legal apparatus so that the perpetrators were free to steal openly.

The location of the theft is mostly done in places that are easily seen by others; one of them is in Mall Tatura, Palu City. The perpetrators did not hesitate to join in taking the goods in the mall because, at that time, many people also stole at the place or more accurately referred to as looting. Stolen goods are electronic devices, building materials, to agricultural products. No stolen goods are included in the type of basic needs. The theft was carried out with a variety of modus operandi, one of which was because the perpetrator heard the news of scattered items so that the perpetrator along with his friends went to the location using a truck/minivan and took the scattered items. Knowing this modus operandi can be assessed that the crime of theft, as explained in the NKK theory that where there are intention and opportunity, then there is a crime. ${ }^{21}$

Theft is done not out of necessity. Therefore, the crime of theft at the time of natural disasters and after natural disasters in Palu City is affected by natural disasters as a factor of opportunity.

Initial efforts made to prevent any chance of committing a crime are preemptive efforts. These efforts originate from NKK theory, where the intention factor becomes lost even though at that time, there was an opportunity because of a good value or norm that was embedded in a person. ${ }^{22}$

\footnotetext{
${ }^{20}$ Nasrun Pasaribu et al., Op.Cit.,36.

${ }^{21}$ A.S. Alam, Amir Ilyas, Op.Cit.,93.

${ }^{22}$ Andini L. Tamara, Winarno Budyatmojo. "Kajian Kriminologi Terhadap Pelaku Pelecehan Seksual yang Dilakukan oleh Wanita Terhadap Pria", Recidive 8, no. 2, (2019): 139-148.
} 
Crime prevention efforts were also put forward by E. H. Sutherland and Cressey which were divided into 2 (two) methods, including the first, a method for reducing the repetition of crime through conceptual guidance which is called as a repressive effort; and secondly, the method to prevent someone from committing a crime for the first time (the first crime) called preventive effort. ${ }^{23}$

\section{The Role of the Government in Preventing Theft During and After Natural Disasters}

The efforts made by the government in preventing the crime of theft during and after the occurrence of natural disasters that on the day of the incident, the first as a preventive effort, have been held free kitchens and have carried out logistics distribution. But the obstacle at that time were very many victims who fled and spread. Disaster victims who fled did not gather at one point of refugee that had been determined. So that aid is not well distributed. ${ }^{24}$

The panic factor at that time was the fear of the unavailability of food in the long run. Finally, even though they already have food, they tend to hoard supplies. Some already have instant noodles, but plus more. There is rice, plus more. At the time of the incident, the first thing to do was to use the remaining logistics, there was rice from the National Logistics Agency (BULOG) and to purchase or take goods from outside in the shop which were still available and then collected to help the community.

The assistance from outside only arrived on the 3rd day, which was Sunday, but before that the logistics provided remained distributed but did not meet, and there was panic. At that time the condition was that people did not have money, because all public facilities, the electricity went out, which we had taken first. Donation assistance in the form of new money enters through an account by way of transfer 3 or 4 days after a natural disaster.

The first aid that came in from KRI Nusantara. Crimes occur because of a form of public panic. Finally, there is excess inventory, some are right, and there are none at all.

External assistance should ideally be taken over by the Korem, including the distribution of aid, but the distribution of aid is experiencing problems because it is not well distributed. There should be proposals for assistance then distributed through each village head. According to the testimony of the Head of Emergency and Logistics Division Mohammad BambangSabarsyah, on Saturday, September 29, 2018, around 2 pm there was 1 (one) Alfamidi whose door was half open and inside there were 2 (two) Alfamidi employees, then he wanted to enter buying necessities. However, the Alfamidi employee gave 1 (one) instant fried noodle dos for free. In other places there were deliberately

\footnotetext{
${ }^{23}$ Romli Atmasasmita, Bunga Rampai Kriminologi (Jakarta: Rajawali, 1983), 66.

${ }^{24}$ Interview with the Head of Emergency and Logistics Division of the Palu City Disaster Management Agency, Mohammad Bambang Sabarsyah, on October 24, 2019.
} 
dismantled, some were open but without guard and lack of officers because at that time many police officers were victims of natural disasters while guarding for the anniversary of Palu City on Talise Beach.

The cause of theft is because people deliberately take advantage of the opportunities that exist. However, some people choose to take goods solely to make ends meet. The crime of theft is always started by groups who first demolished the place.

Government's role during and after natural disasters only focus on meeting the needs of victims of natural disasters. This needs to be further addressed by law enforcement officials.

\section{The Involvement of Law Enforcement Officers in Overcoming Theft Crimes During and After Natural Disasters}

Government's role during and after natural disasters only focus on meeting the needs of victims of natural disasters. This needs to be further addressed by law enforcement officials. Thus, the Palu City Police (Satreskrim Polres) law enforcement officers also made efforts both preventive and repressive.

The efforts made by the Palu Police in the prevention and handling of theft that occurred during and after the occurrence of natural disasters include several stages. First, on Saturday, September 29, 2018, until Sunday, September 30, 2018, law enforcement officers, especially the police, carried out preventive efforts, namely the appeal of Security and Public Order (Kamtibmas) through Bhayangkara Trustees of Security and Public Order (Babhinkamtibmas) in villages and villages. To urge its citizens not to loot or steal property belonging to others who have been left for evacuation or save themselves, so that if a perpetrator is found to be stolen during this time, he will only be given a warning. Secondly, on Monday, October 1, 2018, began to make repressive efforts, namely the arrest of perpetrators of looting and legal processing up to the stage of justice, as a form of learning for people who want to commit theft and or looting in various places. ${ }^{25}$

\section{Conclusion}

The role carried out by the government is a preventive effort, including Organizing public kitchens on the day of the incident; Utilization of the remaining available logistics; and make a purchase or take goods in stores to be supplied as preparation. This effort can only prevent theft motivated by a situational factor, namely the urgent needs of victims of a natural disaster. It is essential for the involvement of law enforcement officers, especially the police, to provide security assistance, including:

${ }^{25}$ Interview with Managing Head of Administrative and Administration Affairs (PS Kaurmintu) Satreskrim Palu City Police Precinct Dwi Sarsono, on October 23, 2019. 
1. Preventive efforts to urge its citizens not to loot or steal property belonging to others who have been left for evacuation or save themselves, so that if a perpetrator is found to be stolen during this time, he will only be given a warning on Saturday to Sunday, September 29 to 30, 2018; and

2. Began to make repressive efforts namely the arrest of perpetrators of looting and legal processing up to the stage of justice, as a form of learning for people who want to commit theft and or looting in various places on Monday, October 1, 2018.

\section{References}

Ali, Ahmad. Menguak Teori Hukum (Legal Theory) dan Teori Peradilan (Judicial Prudence) Termasuk Interpretasi Undang-Undang (Legisprudence). Jakarta: Kencana Prenada Media Group, 2009.

Alam, A. S., \& Ilyas, A. Kriminologi Suatu Pengantar. Jakarta: Prenadamedia Group, 2018.

Atmasasmita, Romli. Bunga Rampai Kriminologi. Jakarta: Rajawali, 1983.

Ilyas, Amir. Asas-Asas Hukum Pidana; Memahami Tindak Pidana dan Pertanggungjawaban Pidana Sebagai Syarat Pemidanaan (Disertai TeoriTeori Pengantar dan Beberapa Komentar). Yogyakarta: Rangkang Education, 2012.

Marwan, M., \& P., J. Kamus Hukum: Dictionary of Law Complete Edition. Surabaya: Reality Publisher, 2009.

Soesilo, R. Pencurian. Kitab Undang-Undang Hukum Pidana (KUHP) Serta Komentar-Komentarnya Lengkap Pasal Demi Pasal. Bogor: Politeia,1995.

Agus Suharsoyo, "Karakter Pelaku Tindak Pidana Pencurian dalam Tipologi Kejahatan Pencurian di Wilayah Sukoharjo". Jurisprudence 5, no. 1, 2015:64-74.DOI: https://doi.org/10.23917/jurisprudence.v5i1.4222.

Andini L. Tamara, Winarno Budyatmojo. "Kajian Kriminologi Terhadap Pelaku Pelecehan Seksual yang Dilakukan oleh Wanita Terhadap Pria". Recidive 8, no. 2, 2019: 139-148.

Chintya Dewi RestyanaS. "The Modus Operandi of Children as the Offender in Committing Human (A study in Kepolisian Resor Kota Besar Surabaya)".Fiat Justisia: Jurnal Ilmu Hukum13, no. 1, 2019:75-86. DOI: https://doi.org/10.25041/fiatjustisia.v13no1.1508.

Hariyadi Djamal, Gatot Saptadi."Kajian Model Desa Tangguh Bencana dalam Kesiapsiagaan Penanggulangan Bencana Bersama BPBD Provinsi D.I. Yogyakarta". Jurnal Penanggulangan Bencana 3, no. 2, 2012: 1-13.

Nasrun Pasaribu."Penyidikan Kasus Tindak Pidana Pencurian Dengan

Pemberatan Di Wilayah Hukum Polsek Medan Baru". USU Law Journal 5, no. 1, 2017:30-40.

Oksidelfa Yanto \& Muhammad Iqbal." Protection of Teacher Profession Encountered With The Rule of Criminal Law on Child Protection", 
Tadulako Law Review 4, no. 2, 2019:183-201.

Reddy Mas Sahid."Sosiologi Pemerintahan: Penjarahan Di Kota Palu Faktor, Aktor Dan Penanggulangan". The Indonesian Journal of Politics (IJPP) 1, no. 1, 2019: 83-93.

Wahyu Nugroho. "Disparitas Hukuman Dalam Perkara Pidana Pencurian

Dengan Pemberatan Kajian terhadap Putusan Nomor 590/Pid.B/2007/PN.Smg dan Nomor 1055/Pid.B/2007/PN.Smg". Jurnal Yudisial 5, no. 3, 2012: 261-282. DOI: http://dx.doi.org/10.29123/jy.v5i3.124.

Dewan Perwakilan Rakyat Republik Indonesia. Naskah Rancangan Kitab Undang-undang Hukum Pidana (RKUHP) DPR RI. (2019). Jakarta: Dewan Perwakilan Rakyat Republik Indonesia.

Decision Number 513 / Pid.B / 2018 / PN Pal (pp. 1-11). (2019). Palu, Central Sulawesi: Palu District Court.

Decision Number 525 / Pid.B / 2018 / PN Pal (pp. 1-15). (2018). Palu, Central Sulawesi: Palu District Court. 
(20) 